\title{
Career development orientations of young people in Bulgaria
}

\author{
S. E. Ilieva ${ }^{1}$ \\ ${ }^{1}$ Sofia University St. Kliment Ohridski, \\ 15, Tzar Osboboditel blvd., 1504 Sofia, Bulgaria
}

\begin{abstract}
Author:
Ilieva Snezhana E.

e-mail: sn_ilieva@abv.bg

\section{Funding:}

This research was funded by the Scientific Research Fund of Sofia University, project No. 80-10-104.

Copyright:

(C) The Author (2019).

Published by Herzen State

Pedagogical University of Russia.
\end{abstract}

Abstract. The psychological capital (Luthans, Youssef, Avolio 2007; Luthans, Youssef-Morgan, Avolio 2015), the five basic career anchors defined by E. Schein (Schein 1978; 1990) and career development expectations of young people are explored using the framework of boundaryless career. The sample consists of 160 respondents divided into two age groups - up to 25 years old and 26-35 years old that are related with the different stages in their career. The respondents of these groups represent two generations that have nowadays and will have also in the near future active participation into the labor market - generation "Y" and generation "Z". There are no differences between them in their career anchors, expectations and psychological capital with exception of security/stability that has higher value among the group of 26-35 years old. The autonomy/independence, managerial competence and entrepreneurial creativity are the leading career anchors of young people. There is no correlation between psychological capital and security/stability career anchor. Young people have clear preferences to work with new technologies, seek a promotion and hierarchical career development and tend to participate in trainings and skill developing programs. They strive to have a long-term perspective of career development and prefer job positions that provide challenging and innovative tasks and gives them opportunities for coaching and talent management. The results from regression analysis indicate that hope as a positive personality resource has effect on the managerial competence, entrepreneurial creativity and autonomy/independence. Hope and optimism are strong predictors of entrepreneurial creativity. Optimism is a main predictor of career development expectations and determines the skills improvement, vertical and horizontal career development and talent management of young people.

Keywords: career anchors, career expectations, psychological capital, boundaryless career, career stages, generation „Y”, generation “Z”. 


\title{
Карьерные ориентации молодежи в Болгарии
}

\author{
С. Е. Илиева ${ }^{1}$ \\ 1 Софийский университет им. Св. Климента Охридского, \\ 1504, Болгария, София, бул. Царь-Освободитель, 15
}

\section{молодых людей. Ведущими}

автономность/независимость, управленческая компетентность и предпринимательское творчество. В нашем исследовании не было выявлено корреляции между психологическим капиталом и безопасностью/стабильностью. Молодые люди имеют сформированные предпочтения, связанные с работой с новыми технологиями, стремятся к продвижению по службе и карьерному росту, склонны участвовать в тренингах и программах повышения квалификации. Они стремятся выстраивать долгосрочную перспективу карьерного развития и предпочитают рабочие места, которые обеспечивают сложные и инновационные задачи, дают возможности для обучения и развития способностей. Результаты регрессионного анализа свидетельствуют о том, что надежда как позитивный личностный ресурс оказывает влияние на управленческую компетентность, предпринимательскую креативность и самостоятельность/независимость. Надежда и оптимизм являются сильными предикторами предпринимательской креативности. Оптимизм является основным предиктором ожиданий в отношении карьерного развития и определяет ориентацию на повышение квалификации, вертикальное и горизонтальное развитие карьеры, развитие способностей.

Ключевые слова: карьерные якоря, карьерные ожидания, психологический капитал, неограниченная карьера, этапы карьеры, поколение Y, поколение Z. психологического капитала (Luthans, Youssef, Avolio основных карьерных якорей, определенных Э. Шейном (Schein 1978; 1990), и ожиданий молодых людей в отношении карьерного развития в контексте идеи 160 респондентов, разделенных на две возрастные группы (до 25 лет и от 26 до 35 лет), которые связаны с различными этапами карьеры. Респонденты время, и в ближайшем будущем активно участвуют в рынке труда, - поколение "Y" и Поколение "Z". Между ними не выявлено различий в их карьерных якорях, карьерных ожиданиях и психологическом капитале, за исключением безопасности/стабильности, которая имеет более высокую ценность для группы 26-35-летних карьерными якорями молодежи являются

\author{
Сведения об авторе: \\ Сведения об авторе:
Илиева Снежана Евлогиева \\ e-mail: sn_ilieva@abv.bg \\ Финансирование: \\ Исследование выполнено при \\ финансовой поддержке Научно- \\ исследовательского центра \\ Софийского университета, \\ проект № 80-10-104. \\ (C) Автор (2019). \\ Опубликовано Российским \\ государственным педагогическим \\ университетом им. А. И. Герцена.
}

Аннотация. В статье описаны результаты исследования 


\section{Introduction}

The tendencies in career and perspectives that are marked out for the young generations, who enter into the labor market began to be discussed back in 1990's. It is considered that managing your own career depends on the adaptability of the personality (Savickas 1997). Adaptability to career transitions refers to personality resources for coping, which influence decision making, curiosity about new alternatives and options for career choice, attitudes to future career development and also personal control over the activities regarding career (Savickas 2013).

Significant part of the theories, developed in the $20^{\text {th }}$ century, consider career as a predictable process but at the beginning of the $21^{\text {st }}$ century it was thought that the organizational career, where a person is being developed and grows at one and the same workplace, was unlikely. The traditional career understood as institutional or organizational is starting to be replaced with unconventional and alternative types of career such as Protean career (Hall 1996) and the boundaryless career (Arthur, Rousseau 1996). Career in the new century has a fragmentary and changeable nature and could be managed by the person during his/her whole life (Hall 1996; Schein 1996).

Protean career varies at its forms and includes alternative options such as entrepreneurship, work from home and self-hired work. It is not vertical but mostly horizontal and contains enrichment of knowledge and skills. This new type of career requires a development of the so-called meta-competencies such as learning how to learn new things aimed to adapt to career challenges and transitions during personal life (Hall 1996). The values in Protean career are not loyalty and commitment to a certain organization but personal freedom, self-expression, achieving of personal goals and maintaining balance between work and personal life.

Boundaryless career contains a sequence of opportunities to work outside of a certain organization (Arthur, Rousseau 1996; Arthur
2014) and it seems very similar to Protean career concept. Boundaryless career obligatory includes mobility, which can be real or physical, concerning transition between professions, job positions and employers, or psychological, which is expressed in attitude for work in a different environment (Briscoe, Hall, Frautschy, DeMuth 2006).

Career identity is based on the so-called career "anchors" or orientations of the personality, which were introduced by E. Schein (Schein 1990) as a way to integrate personal characteristics such as skills, motives, values and attitudes. They evolve and change in the personal life as a result of working experience, but at the same time they act as an "anchor" that determines career choices, planning and development. Career anchors also create a stable personal self-esteem, give stability and determines the future career decisions in a predictable way (Schein 1990).

Initially E. Schein distinguishes five career anchors or orientations that include competencies, talents, values and motives of the personality - technical/functional competence, general managerial competence, security/stability, entrepreneurial creativity and autonomy/independence (Schein 1990). Afterwards E. Schein added three more main career anchors or orientations - dedication to a cause, pure challenge and lifestyle (Schein 1996). The factor analysis reveals that the entrepreneurship and creativity are two separate factors (Danziger, RachmanMoore, Valency 2008).

The changes in the nature and content of work in the informational society foster necessity of flexible and diverse forms of career and substantially change the expectations of young generations, regarding professional realization and career development. Traditional organizations cannot answer the striving of young people oriented to diversity, challenges, autonomy, self-expression and quality of life. Many questions are being asked about job expectations, motivation and retention of young people at work. Assumptions are being held, that they will be more likely to aim for flexible and diverse 
forms of career, will seek Protean or boundaryless career and will have preferences towards entrepreneurial initiative, to be self-hired, to start and develop their own business, instead of looking for a career in large organizations as it was in previous generations.

Young people that are currently participating in the labor market are representatives of two generations, generation "Y" and the so-called "millennials" or "children of the millennium", which represent a main part of the labor force at the moment, and generation "Z", which covers people born after 1995 and is now joining or is preparing to join the labor market. Both of them are technologically oriented, but generation "Z" is referred to as the digital generation (Levickaite 2010). Generation "Y" is characterized with pragmatic values, which combine freedom and comfortable life, enjoys teamwork, but also relies on itself. Modern technologies and Internet are a way of life for this generation, while financial success, quality of life and balance between work and personal life are equally important. Generation "Z", on the other hand, lives both in the real and the virtual world and can easily manage to "jump" from one to the other. It is characterized with a striving for an exciting and challenging career, seeks independence and the thing that differentiates it from other generations is not stability but mobility (Dolot 2018). It is thought that this generation will, more than others, aim to start its own business or to be self-hired as such type of career gives autonomy, flexibility and mobility.

The new generation could develop its own personal potential to reach a career success and to fit the challenges of labor market. Psychological capital is introduced in positive psychology as a concept that goes beyond the concept of human capital and concerns the personal capacity and potential (Luthans, Youssef-Morgan, Avolio 2015). It is defined as an individual positive state that consist of four components - self-efficacy, optimism, hope and resilience.

Hope is related to work performance, job satisfaction, organizational commitment and the feeling of happiness. The people with high selfefficiency are self-motivated, welcome and thrive on challenges, they set high goals for themselves and invest needed efforts to attain their goals. Optimism is expressed in positive expectations of the personality. It is needed during changes and uncertainty that characterize modern organizations and establish new challenges in the career. Optimism has positive effect on career and personal development if it is realistic and flexible. Resilience is the positive adaptation when a risk factor or situation occurs. Career resilience is the striving to constantly study and take responsibility for managing of the own career. It includes a new psychological contract between employees and organizations and holds the idea for the development of employees through learning their whole life, which increases their opportunities and favors career adaptability (Luthans, Youssef-Morgan, Avolio 2015).

Significant relationships between psychological capital and career adaptability were found (Safavi, Bouzari 2019). Psychological capital predicts the subjective well-being and career commitment of employees (Singhal, Rastogi 2018). Optimism as a component of psychological capital is significant predictor of entrepreneurial success (Baluku, Kikooma, Kubanja 2016).

Therefore the aim of the current study it to explore the career anchors and expectations of young people belonging to two generations that is an important part of current and future labor force and to explore an influence of psychological capital on their career development orientations.

\section{Methods and sample}

The methods include three questionnaires two of them are intended to measured career orientations and the third one measures the four components of psychological capital.

Career anchors questionnaire measures five basic anchors, defined by E. Schein (Schein 1990) and is a short version with 15 items, assessed on 5-point Likert scale. A coefficient of internal consistency alpha of Cronbach in this study is 0,92 . 
Career development expectations questionnaire is developed for the current study. It consists of 11 items and is measuring the expectations to hierarchical promotion and advancement, horizontal career and job rotation, skills development, participation in different career development programs such as talent management and coaching. The alpha of Cronbach is 0,88 .

Psychological capital questionnaire consists 24 items, divided in four dimensions - self-efficacy, hope, optimism and resilience (Luthans, Youssef, Avolio, 2007). A coefficient of internal consistency alpha of Cronbach in this study is 0,93 .

160 respondents took part in study. $52 \%$ of them are male and $48 \%$ are female. They are young people divided in two groups by age $45 \%$ are till 25 years old and $55 \%$ are on age between 26-35 years old. They have completed their higher education degree (60\%) or are students (40\%), who are working during their university study. All of them have fulltime or part-time job positions in organization where information technologies are applied The respondents are on different stages in their career according the typologies of career development (Savickas 1995; Schein 1990). First age group till 25 years old represents "Z" genera- tion who starts their first jobs and is at the beginning of its career path. Individuals in their mid-twenties are within a stage of exploration and narrow their work preferences. Several career expectations could be unrealistic but individuals within this age seek opportunities to explore careers through work experience and try a variety of job activities in a number of organizations. The second age group (26-35 years old) represents "Y" generation. They are in their establishment career stage where their expectations and preferences are stabilized and are realistic. These individuals are highly motivated to succeed and strive for challenge, creativity, achievement and development of their own personal potential. The representatives of those two generations are active workforce at the current moment and their career expectations and orientations should be considered in HRM strategies and practices.

\section{Results and discussion}

The descriptive statistics, t-test, correlation and regression analysis were conducted. The results of descriptive statistics indicate that hope has the highest value, followed by the perception of self-efficacy, while resilience and especially optimism have lowervalues (Table 1).

\section{Table 1. Descriptive statistics for psychological capital dimensions}

\begin{tabular}{|l|l|c|}
\hline Psychological capital & Mean & Std deviation \\
\hline Self-efficacy & 24,38 & 3,16 \\
\hline Optimism & 23,01 & 3,61 \\
\hline Hope & 25,72 & 3,42 \\
\hline Resilience & 23,96 & 2,96 \\
\hline
\end{tabular}

High values of hope indicate favorable expectations concerning career development while lower values of resilience and optimism probably show realism of the expectations of the personality to development of career. The t-test didn't establish differences regarding components of psychological capital between the representatives of the two generations.

Career orientations of the studied young people are aimed towards autonomy and inde- pendence followed by managerial competency and entrepreneurial creativity while security/stability and functional/technical competency are being rated low. The results for the $t$ test show that as a whole there are no age differences in career orientations of young people. The age difference was established only in security/stability orientation that is higher among older respondents between 26-35 years old $(t=4,538, p<0,01)$ (Table 2$)$. 


\section{Table 2. Descriptive statistics for career anchors}

\begin{tabular}{|l|l|c|}
\hline Career anchors & Mean & Std deviation \\
\hline Functional/technical competence & 10,78 & 2,15 \\
\hline General managerial competence & 12,44 & 2,53 \\
\hline Security/stability & 11,98 & 1,61 \\
\hline Entrepreneurial creativity & 12,19 & 2,1 \\
\hline Autonomy/independence & 13,78 & 1,89 \\
\hline
\end{tabular}

The results from descriptive statistics indicate the expectations of young people are to work with new technologies, to strive to promotion and hierarchical career development and to take part in trainings and skills, development programs and long-term projects (Table 3). The t-test analysis was made to explore the differences between the age groups. There are no dif- ferences between the two age groups. The respondents have an orientation more to hierarchical career than to horizontal career and prefer to engage in long-term work projects as well as to develop themselves working in innovative and challenging projects and job tasks. They also tend to invest in improvement of their skills including professional, new and diverse and soft skills.

\section{Table 3. Descriptive statistics for career development expectations}

\begin{tabular}{|l|c|c|}
\hline \multicolumn{1}{|c|}{ Career development expectations } & Mean & $\begin{array}{c}\text { Std } \\
\text { deviation }\end{array}$ \\
\hline Engagement in long-term projects & 3,86 & 0,967 \\
\hline Challenging and innovative projects & 3,71 & 0,965 \\
\hline Work with new technologies & 4,06 & 0,778 \\
\hline $\begin{array}{l}\text { Promotion and hierarchical career } \\
\text { development }\end{array}$ & 3,99 & 1,014 \\
\hline $\begin{array}{l}\text { Participation in trainings and skills } \\
\text { improvement programs }\end{array}$ & 3,87 & 0,850 \\
\hline Job rotation & 2,91 & 0,928 \\
\hline Work with mentor & 2,99 & 1,110 \\
\hline Development of soft skills & 3,11 & 0,925 \\
\hline Participation in talent management program & 2,61 & 1,011 \\
\hline Coaching & 2,57 & 1,031 \\
\hline Development of new and diverse skills & 3,66 & 0,961 \\
\hline
\end{tabular}

The results from the correlation analysis show relationships between the components of psychological capital and career orientations. There is no correlation only with career anchors of security/stability. All components of psychological capital correlate with the remaining career anchors as they are highest regarding the orientation to entrepreneurial creativity, which shows that individuals who aim to develop their potential and have personality resources, tend to develop entrepreneurial initiative. Optimism and hope are connected more to entrepreneur- ship, managerial competency and autonomy/independence while other components of psychological capital have lower correlations with career orientations.

A regression analysis is made using the stepwise regression method to establish an effect of psychological capital on career anchors (Table 4). Self-efficacy does not have influence on any career orientation. Resilience of the personality impacts the functional/professional competency as it explains $19 \%$ of the variance. This component of psychological capital does not influence other career orientations. 
Table 4. Results from regression analysis of impact of psychological capital on career anchors Significance levels: ${ }^{* * *} \mathrm{p}<0,001 ;{ }^{* *} \mathrm{p}<0,01 ;{ }^{*} \mathrm{p}<0,05$

\begin{tabular}{|c|c|c|c|c|c|}
\hline \multirow{2}{*}{$\begin{array}{c}\text { Career } \\
\text { anchors }\end{array}$} & \multicolumn{4}{|c|}{ Psychological capital } & \multirow{2}{*}{$\begin{array}{l}\text { Adjusted } \\
\text { R square }\end{array}$} \\
\hline & $\begin{array}{c}\text { Self- } \\
\text { efficacy }\end{array}$ & Optimism & Hope & Resilience & \\
\hline $\begin{array}{l}\text { Functional/ } \\
\text { technical } \\
\text { competence }\end{array}$ & & & & $0,435 * * *$ & 0,19 \\
\hline $\begin{array}{l}\text { General } \\
\text { managerial } \\
\text { competence }\end{array}$ & & & $0,572 * * *$ & & 0,31 \\
\hline \multicolumn{6}{|l|}{$\begin{array}{l}\text { Security/ } \\
\text { Stability }\end{array}$} \\
\hline $\begin{array}{l}\text { Entrepreneurial } \\
\text { creativity }\end{array}$ & & $0,445 * * *$ & $0,357^{* *}$ & & 0,54 \\
\hline $\begin{array}{l}\text { Autonomy/ } \\
\text { Independence }\end{array}$ & & & $0,396 * * *$ & & 0,14 \\
\hline
\end{tabular}

Hope predicts the managerial competency, autonomy/independence and entrepreneurial creativity. Hope has the strongest influence on the development of managerial competency $(\beta=0,572, p<0,001)$. The entrepreneurial creativity is influenced by optimism and hope that explain $54 \%$ of the variation. Resilience is a determinant of functional /technical competence where explains $19 \%$ of variance. Self-efficacy has no effect on career anchors.
The results from correlation analysis show significant relationships between all components of career expectations with psychological capital. The relationships between optimism and hope with career expectations are higher than these with resilience and self-efficacy. That is why a regression analysis was made to establish the impact of psychological capital components on career expectations (Table 5).

Table 5. Results from regression analysis of impact of psychological capital on career expectations. Significance levels: ${ }^{* * *} \mathrm{p}<0,001 ;{ }^{* *} \mathrm{p}<0,01 ;{ }^{*} \mathrm{p}<0,05$

\begin{tabular}{|l|l|l|l|l|l|}
\hline \multirow{2}{*}{ Career anchors } & \multicolumn{3}{|c|}{ Psychological capital } & Adjusted \\
\cline { 2 - 5 } & $\begin{array}{c}\text { Self- } \\
\text { efficacy }\end{array}$ & Optimism & Hope & Resilience & R \\
\hline $\begin{array}{l}\text { Engagement in } \\
\text { long-term projects }\end{array}$ & & $0.424^{* * *}$ & & & 0,168 \\
\hline $\begin{array}{l}\text { Challenging and } \\
\text { innovative } \\
\text { projects }\end{array}$ & $0,646^{* * *}$ & & & 0.409 \\
\hline $\begin{array}{l}\text { Work with new } \\
\text { technologies }\end{array}$ & & $0,553^{* * *}$ & & & 0,295 \\
\hline $\begin{array}{l}\text { Promotion and } \\
\text { hierarchical career } \\
\text { development }\end{array}$ & & $0,288^{*}$ & $0,441^{* * *}$ & & 0,448 \\
\hline $\begin{array}{l}\text { Participation in } \\
\text { trainings and } \\
\text { skills } \\
\text { improvement } \\
\text { programs }\end{array}$ & & & $0,464^{* * *}$ & & 0,204 \\
\hline Job rotation & & & $0,463^{* * *}$ & & 0,203 \\
\hline Work with mentor & & $0,298^{*}$ & & $0,428^{* * * *}$ & 0,172 \\
\hline $\begin{array}{l}\text { Development of } \\
\text { soft skills }\end{array}$ & & $0,502^{* * *}$ & & & 0,075 \\
\hline $\begin{array}{l}\text { Participation in } \\
\text { talent } \\
\text { management } \\
\text { program }\end{array}$ & $0,682^{* * *}$ & & $0,299^{*}$ & & 0,241 \\
\hline Coaching & & & & 0,251 \\
\hline $\begin{array}{l}\text { Development of } \\
\text { new and diverse } \\
\text { skills }\end{array}$ & $0,277^{*}$ & & & & \\
\hline
\end{tabular}


Optimism has highest effect on an expectation to participate in coaching program on workplace $(\beta=0,682, p<0,001)$, to be involves in challenging and innovative projects $(\beta=0,682$, $\mathrm{p}<0,001)$ and work with new technologies $(\beta=0,553, p<0,001)$. Young people that have optimistic attitude are motivated to participate in talent management program and to be engaged in long-term projects. There is a statistically significant but weak effect of optimism on soft skills development in their career.

An orientation to promotion and hierarchical career development is determined by the hope $(\beta=0,0,441, p<0,001)$ and optimism $(\beta=0$, $0,288, p<0,05$ ) that explained $45 \%$ of variance in this career expectation. Hope has an effect on participation in trainings and skills improvement programs and job rotation where explains $20 \%$ of variance. Hope and self-efficacy are predictors of development of new and diverse skills where explains $25 \%$ of variance. Resilience is not predictor of career expectation as a whole and impacts only the willingness to work with mentor where explains $17 \%$ of variance.

\section{Conclusions}

The area of information technologies where the studied young people work corresponds to the criteria for Protean or boundaryless career. The career transitions in this area are typical and include physical mobility and changing of employers and organizations as well as attitude for changing job positions and employers. This impose continuous improvement of skills, longlife learning, and psychological capital who enable the individual adaptability.

Career profile of the young people combines autonomy/independence, managerial competency and entrepreneurial creativity. The autonomy is a leading career anchor and confirms the assumption that the new generations strive to be more independent and to have self-control in their jobs. This creates career expectation which gives opportunity for personal control, flexibility and aims to go beyond organizational restrictions, rules and procedures. The opportu- nities for hierarchical career growth are desirable but only if they allow engagement in innovative projects that satisfy the entrepreneurial orientation of the young people. They are ready to develop diverse skills, to be engaged in different challenging innovative projects and to participate in variety of career and personal development programs such as talent management and coaching. The results confirm that components of psychological capital and especially optimism and hope influence career orientations.

The young people in this study have high values on hope as a component of psychological capital which is considered as an important psychological resource (Luthans, Youssef, Avolio 2007; Luthans, Youssef-Morgan, Avolio 2015). Most of the employees with high values of hope aim to be independent, have internal locus of control, seek autonomy and have a need for achievement and personal development. They are creative, look for unconventional solutions, challenge the status quo and can undertake high risks, which gives them reason to be characterized as successful entrepreneurs (Luthans, Youssef-Morgan, Avolio 2015). Hope determines the three career orientations - managerial competency, autonomy/independence and entrepreneurial creativity as well as the expectations for developing new skills and rotation of job positions.

Optimism and hope predict the entrepreneurship and creativity in young people. Optimism determines the expectations for career development in innovative activities, participation in diverse projects and programs for developing skills and talent management.

The lack of differences between two age groups, which include representatives of both generation "Y" and "Z", gives reason to conclude that they have similar values, motives and expectations regarding their career development. These results could be used in process of attraction, motivation and retention of young people and HRM practices in organizations. 


\section{References}

Arthur, M. B. (2014) The boundaryless career at 20: Where do we stand, and where can we go? Career Development International, vol. 19 (6), pp. 627-640. (In English)

Arthur, M. B., Rousseau, D. M. (1996) Introduction: The boundaryless career as a new employment principle. In: Arthur, M. B., Rousseau, D. M. (eds.) The boundaryless career: $A$ new employment principle for a new organizational era.. NY: Oxford University Press, pp. 3-20. (In English)

Baluku, M., Kikooma, J., Kubanja, G. (2016) Psychological capital and the startup capital - entrepreneursial success relationship. Journal of Small Business and Entrepreneurship, vol. 28 (1), pp. 27-54. (In English)

Briscoe, J., Hall, D., Frautschy DeMuth, R. (2006) Protean and boundaryless careers: An empirical exploration. Journal of Vocational Behavior, vol. 69, pp. 30-47. (In English)

Danziger, N., Rachman-Moore, D., Valency, R. (2008) The construct validity of Schein's career anchors orientation inventory. Career Development International, vol. 13 (1), pp. 7-19. (In English)

Dolot, A. (2018) The characteristic of Generation Z. "E-mentor", vol. 2 (74), pp. 44-50. DOI: 10.15219/em74.1351. (In English)

Hall, D. (1996). Protean career of the 21 $1^{\text {st }}$ century. Academy of Management Executive, vol. 10 (4), pp. 8-16. (In English)

Levickaite, R. (2010) Generations X, Y, Z: How social networks form the concept of the world without borders. The case of Lithuania. LIMES: Cultural regionalistics, vol. 3 (2), pp. 170183. (In English)

Luthans, F., Youssef-Morgan, C., Avolio, B. (2007) Psychological capital and beyond. Oxford: Oxford University Press, 336 p. (In English)

Safavi, H., Bouzari, M. (2019) The association of psychological capital, career adaptability and career competency among hotel frontline employees. Tourism management perspectives, vol. 30, pp. 65-74. (In English)

Savickas, M. L. (1997) Career adaptability: An integrative construct for life-span, life-space theory. Career Development Quarterly, vol. 45, pp. 247-259. (In English)

Savickas, M. L. (2013) Career construction theory and practice. In: Lent, R. W., Brown, S. D. (eds.) Career development and counseling: Putting theory and research to work. Wiley, pp. 147-183. (In English)

Schein, E. (1990) Career anchors. Discovering your real values. San Francisco: Jossey-Bass Pfeiffer, 67 p. (In English)

Schein, E. (1996). Career anchors revisited: Implications for career development in the 21st century. Academy of Management Executive, vol. 10 (4), pp. 80-88. (In English)

Singhal, H., Rastogi, R. (2018) Psychological capital and career commitment: The mediating effect of subjective well-being. Management Decision, vol. 56 (2), pp. 458-473. (In English) 